\title{
Metabolic Effects of the Steroid Antibiotic Fusidic Acid
}

\author{
VICTOR WYNN,* M.D.
}

Fusidic acid, the sodium salt of which is known as Fucidin, is an antibiotic which contains the cyclopentanoperhydrophenanthrene ring system and thus belongs to the steroids or tetracyclic triterpenes. Its empirical formula is $\mathrm{C}_{31} \mathrm{H}_{48} \mathrm{O}_{6}$. The structure, which has been confirmed (Arigoni et al., 1964), is shown in Fig. 1. The formulae for the related antibiotics cephalosporin $\mathrm{P}_{1}$ and helvolic acid are also shown in Fig. 1 (Baird et al., 1961 ; Allinger and Coke, 1961).
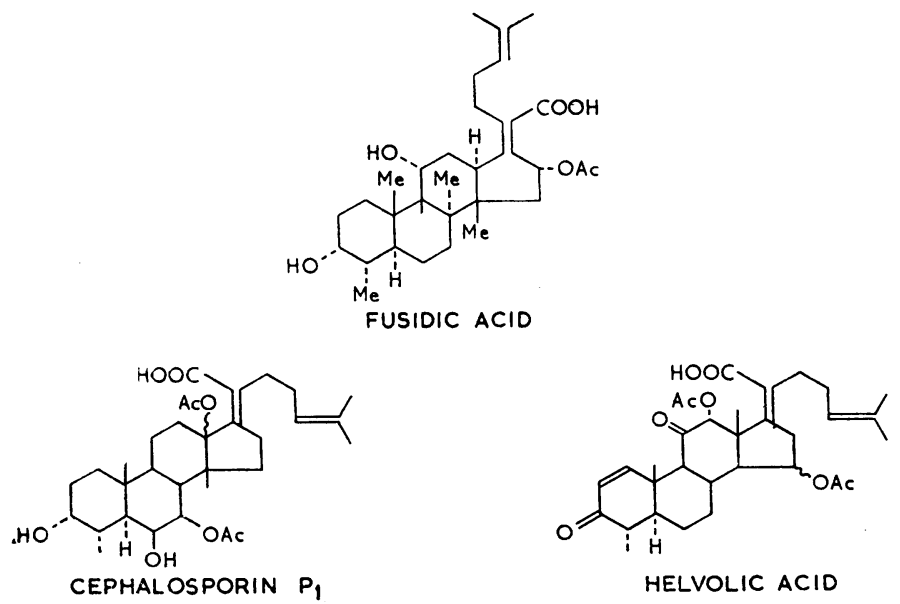

FIG. 1.-Formulae of fusidic acid, cephalosporin $P_{1}$, and helvolic acid.

Fusidic acid was isolated from the fermentation products of the fungus Fusidium coccineum (Godtfredsen et al., 1962a). Fusidic acid shows a high antibiotic activity against the staphylococcus (Godtfredsen et al., 1962b), being 8 and 16 times more active than the related compounds cephalosporin $\mathrm{P}_{1}$ and helvolic acid respectively.

Since Fucidin (sodium fusidate) became available for clinical work it has established itself as an effective antibiotic in staphylococcal infections (Scowen and Garrod, 1962 ; Taylor and Bloor, 1962 ; Crosbie, 1963 ; Dodson, 1963). In chronic infections it may be necessary to give the drug continuously for several weeks or months (Crosbie, 1963 ; Dodson, 1963).

It is clearly important that a complex drug, which is intended for use in man and whose administration may sometimes be prolonged, should have an insignificant effect, if any, upon the patient's metabolism as a whole. This principle is sometimes overlooked with untoward effects-for example, when tetracyclines are used in the presence of renal disease (Shils, 1962, 1963) or in pregnancy complicated by pyelonephritis (Schultz et al., 1963 ; Whalley et al., 1964). The investigations described here have been carried out to see if Fucidin has measurable effects upon a variety of metabolic parameters in man.

\section{Subjects and Procedures}

Four studies have been carried out in patients while they were in the metabolic ward. Clinical data about these patients are shown in Table I. The dose of Fucidin administered was 1.5 or $2 \mathrm{~g}$./day in the form of enteric-coated tablets. In all four

* Reader in Human Metabolism, St. Mary's Hospital, London. patients the infective element was minor, and it was thought most unlikely that any metabolic changes observed could be due to the antibiotic action of Fucidin.

\begin{tabular}{|c|c|c|c|c|c|}
\hline & & Case 1 & Case 2 & Case 3 & Case 4 \\
\hline $\begin{array}{l}\text { Age } \quad . \\
\text { Sex } \quad \ldots \\
\text { Diagnosis }\end{array}$ & $\begin{array}{l}\cdots \\
\cdots \\
\cdots\end{array}$ & $\begin{array}{l}\quad 52 \\
\text { Female } \\
\text { Convalescing } \\
\text { from intes- } \\
\text { tinal fistula }\end{array}$ & $\begin{array}{l}\quad 24 \\
\text { Female } \\
\text { Acne vulgaris }\end{array}$ & $\begin{array}{l}\quad 25 \\
\text { Female } \\
\text { Acne } \\
\text { conglobata }\end{array}$ & $\begin{array}{l}\text { Male } \\
\text { Acne } \\
\text { conglobata }\end{array}$ \\
\hline $\begin{array}{l}\text { Weight (kg.) } \\
\text { Dose of Fuci }\end{array}$ & idin: & 38 & $60 \cdot 5$ & $56 \cdot 0$ & $81 \cdot 0$ \\
\hline $\begin{array}{l}\text { g./day } \\
\text { mg./kg. }\end{array}$ & $\therefore$ & $40^{1 \cdot 5}$ & $25^{1.5}$ & 36 & $16^{1 \cdot 5}$ \\
\hline
\end{tabular}

The patients received a constant food and fluid intake throughout the study. The following investigations were made:

1. Data were established for the external balance of nitrogen, sodium, potassium, and calcium in each patient. Urine was analysed daily but faeces were collected for three days between analyses. Faecal markers were not used. An initial " run-up " period of seven days preceded the quantitative studies. The control period varied from seven to nine days. The period of Fucidin administration varied from 10 to 40 days. In Cases 1 and 2 two periods of drug administration were studied with control studies before and after each use of the drug. In Case 3 the Fucidin was continued for 40 days, with a control period before and after the drug was stopped.

2. Liver-function studies-namely, serum bilirubin, alkaline phosphatase, thymol turbidity, serum glutamic oxalic transaminase (S.G.O.T.) and glutamic pyruvic transaminase (S.G.P.T.) activities, plasma total protein, albumin and globulin levels, and the percentage retention of bromsulphthalein.

3. Studies of carbohydrate metabolism-namely, fasting bloodsugar levels and oral glucose-tolerance and insulin-sensitivity tests.

4. Studies of adrenal and pituitary function-namely, bloodcortisol levels, the urinary excretion of 17 -oxosteroids and 17oxogenic steroids, the blood-cortisol response to insulin hypoglycaemia, the response to metyrapone, and the half-life of administered cortisol.

5. Faecal fat excretion.

6. Plasma electrolyte and urea levels.

Not all the tests could be carried out on all the patients.

Methods.-The methods used in these investigations have been previously reported in publications from this laboratory (Wynn et al., 1961, 1962 ; Landon et al., 1962a, 1962b, 1963 ; James et a!., 1962).

\section{Results}

1. Metabolic Balance Data (Figs. 2, 3, 4, and 5 ; Tables II, III, IV, and V)

Nitrogen Balance.-In Cases 1, 2, and 3 there is evidence of a slight but consistent catabolic effect of Fucidin. In these three cases there are six periods in which it is possible to compare the urine-nitrogen excretion during Fucidin administration with a control period either before or after its administration. The average daily urine-nitrogen excretion is higher in every period of Fucidin administration compared with the control period. On average the difference is $1.1 \mathrm{~g}$. and the range 0.5 to $2.4 \mathrm{~g}$. Faecal nitrogen excretion is unaffected by 
Fucidin. The external nitrogen balance is rendered less positive or slightly negative by Fucidin but the effect is of negligible clinical significance. In Case 3, after a month's administration of the drug the average daily external nitrogen balance was slightly positive $(+1 \mathrm{~g}$.) becoming more so when the drug was stopped $(+1.7$ g.). These data suggest that the catabolic effect persists throughout the period of drug administration, even for as long as 30 days. But the effect is small and does not necessarily cause negative external nitrogen balance. Case 4 gave results which were inconsistent with the above findings. The average daily urine-nitrogen excretion during Fucidin
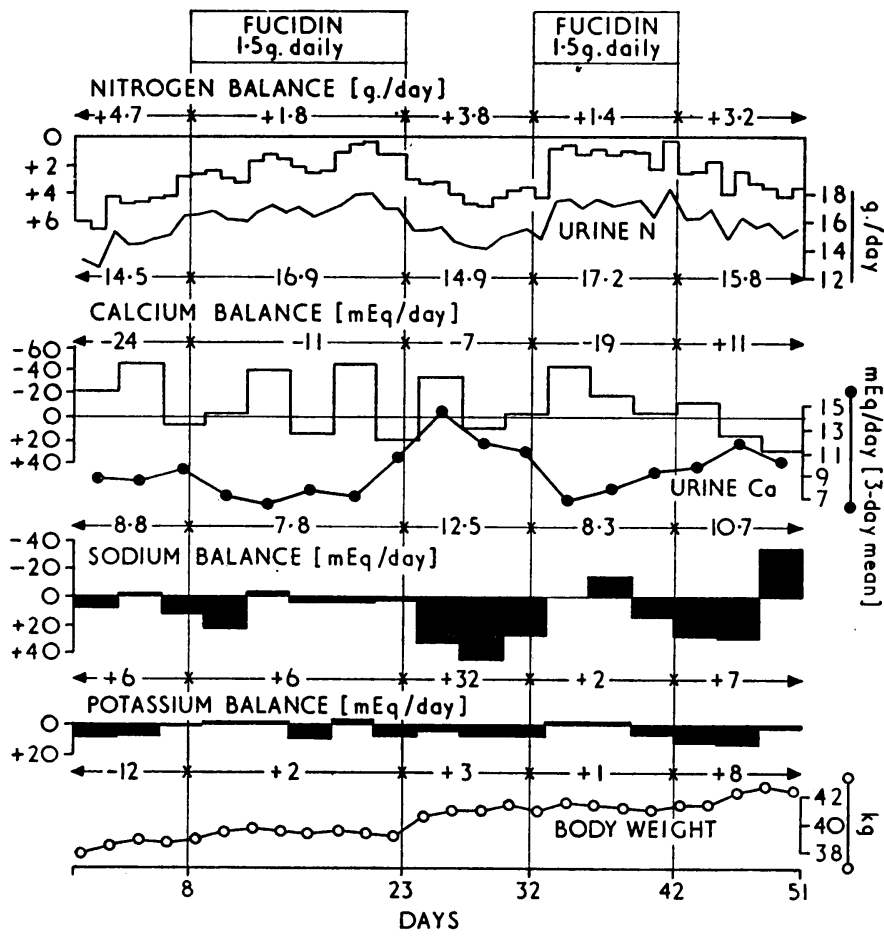

FIG. 2.-Metabolic data in Case 1.

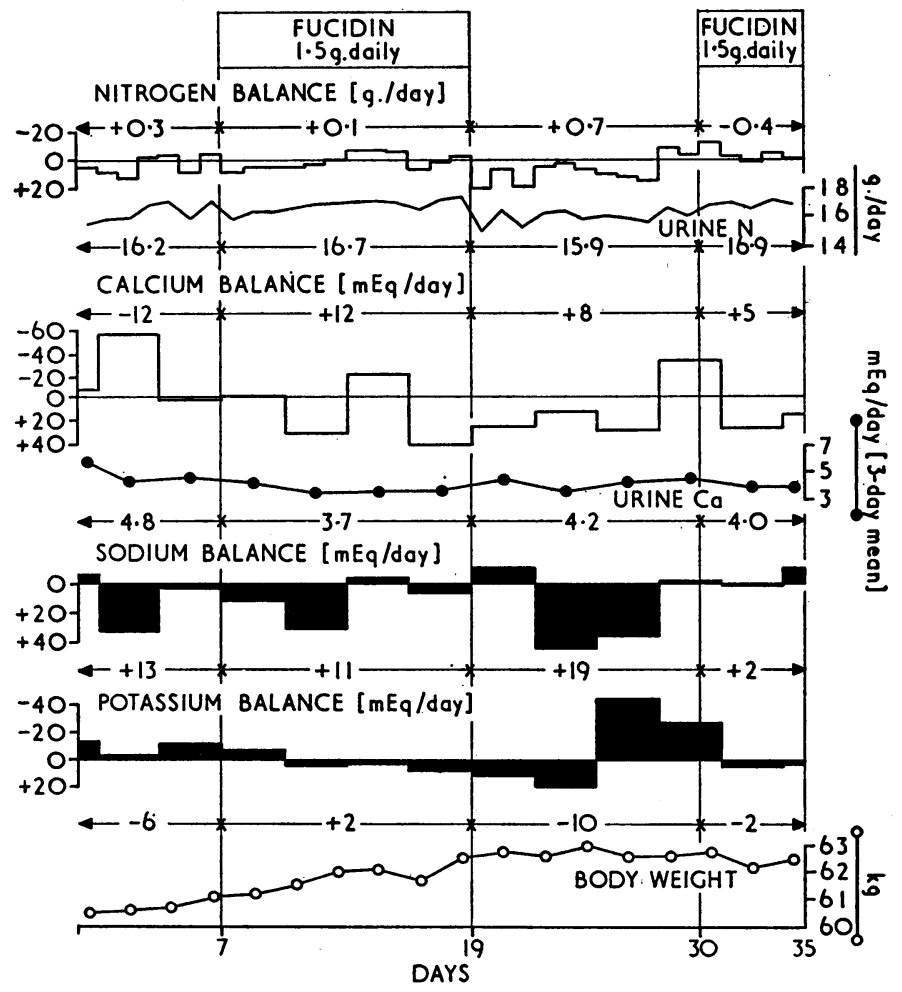

FIG. 3.-Metabolic data in Case 2. administration was $1.1 \mathrm{~g}$. less than during the control period. The control data, however, are complicated by three days of unusually high urine-nitrogen excretion, the significance of which is unknown. The average daily external nitrogen balance during the Fucidin period in this patient was positive $(+1$ g.) compared with the control period in which it was virtually zero $(-0.1$ g.).

Calcium Balance.-The effect of Fucidin upon the external calcium balance was variable and not significant. In three periods the calcium balance was more positive, and in three periods it was less positive than the control periods. The urinecalcium excretion was, however, consistently reduced by Fucidin. In seven periods of observation the average daily urine-calcium excretion was lower than in the control periods,

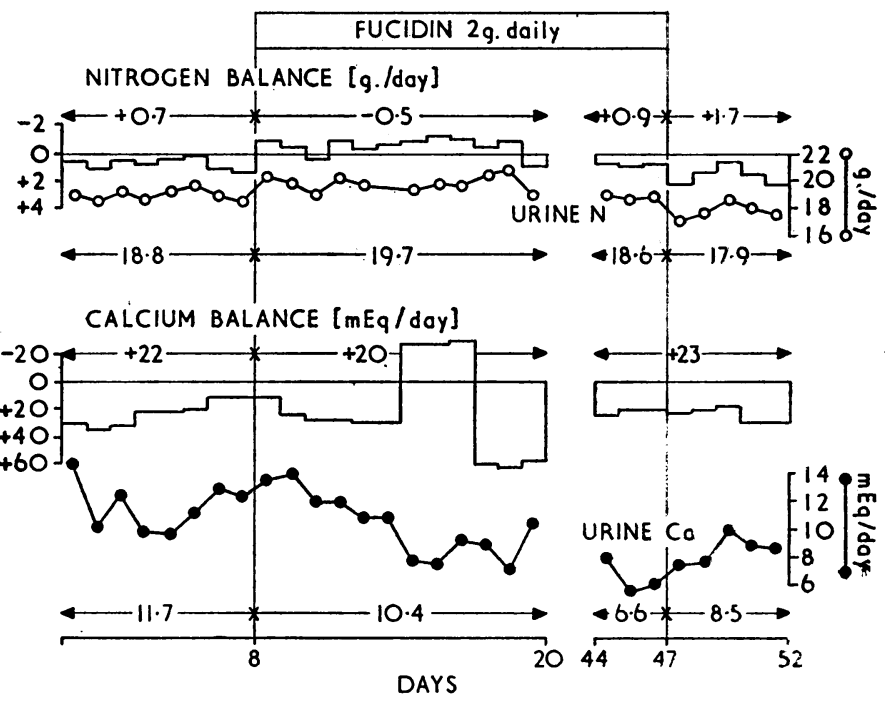

FIG. 4.-Metabolic data in Case 3.

TABle II.-Case 1. Metabolic Balance Data (Food Intake : 2,760 Calories/Day)

\begin{tabular}{|c|c|c|c|c|c|}
\hline No. of Days: & 7 & 14 & 8 & 9 & 8 \\
\hline Treatment: & Nil & Fucidin* & Nil & Fucidin* & Nil \\
\hline 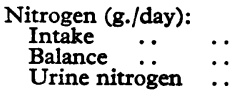 & $\begin{array}{r}19.9 \\
+4.7 \\
14.5\end{array}$ & $\begin{array}{r}19.9 \\
+1.8 \\
16.9\end{array}$ & $\begin{array}{r}19.9 \\
+3.8 \\
14.9\end{array}$ & $\begin{array}{r}19 \cdot 9 \\
+1 \cdot 4 \\
17 \cdot 2\end{array}$ & $\begin{array}{r}19 \cdot 9 \\
+3 \cdot 2 \\
15.8\end{array}$ \\
\hline 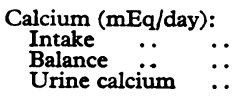 & $\begin{array}{l}102 \\
-24 \\
8 \cdot 8\end{array}$ & $\begin{array}{c}102 \\
-11 \\
7.8\end{array}$ & $\begin{array}{l}102 \\
-72 \cdot 5\end{array}$ & $\begin{array}{l}102 \\
-19 \\
8.3\end{array}$ & $\begin{array}{c}102 \\
+11 \\
10 \cdot 7\end{array}$ \\
\hline 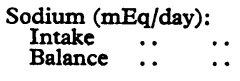 & $\begin{array}{r}116 \\
+6\end{array}$ & $\begin{array}{r}116 \\
+6\end{array}$ & $\begin{array}{r}116 \\
+32\end{array}$ & $\begin{array}{r}116 \\
+2\end{array}$ & $\begin{array}{l}116 \\
+7\end{array}$ \\
\hline $\begin{array}{ccc}\text { Potassium }(\mathrm{mEq} / \text { day }): \\
\text { Intake } \\
\text { Balance }\end{array}$ & $\begin{array}{r}80 \\
+6\end{array}$ & $\begin{array}{r}80 \\
+2\end{array}$ & $\begin{array}{r}80 \\
+3\end{array}$ & $\begin{array}{r}80 \\
+1\end{array}$ & $\begin{array}{r}80 \\
+8\end{array}$ \\
\hline
\end{tabular}

TABLB III.-Case 2. Metabolic Balance Data. (Food Intake : 2,900 Calories/Day)

\begin{tabular}{|c|c|c|c|c|}
\hline No. of Days: & 7 & 12 & 11 & 5 \\
\hline Treatment: & Nil & Fucidin* & Nil & Fucidin* \\
\hline 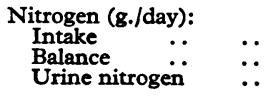 & $\begin{array}{r}18 \cdot 2 \\
+0 \cdot 3 \\
16 \cdot 2\end{array}$ & $\begin{array}{r}18 \cdot 2 \\
+0 \cdot 1 \\
16.7\end{array}$ & $\begin{array}{r}18.2 \\
+0.7 \\
15.9\end{array}$ & $\begin{array}{r}18 \cdot 2 \\
-0.4 \\
16 \cdot 9\end{array}$ \\
\hline 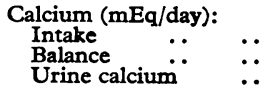 & $\begin{array}{c}84 \\
-12 \\
4 \cdot 8\end{array}$ & $\begin{array}{l}84 \\
+12 \\
3.7\end{array}$ & $\begin{array}{c}84 \\
+8 \\
4 \cdot 2\end{array}$ & $\begin{array}{c}84 \\
+5 \\
4 \cdot 0\end{array}$ \\
\hline $\begin{array}{ccc}\text { Sodium (mEq/day): } & \\
\text { Intake } & \because & \\
\text { Balance } & \because & \end{array}$ & $\begin{array}{r}105 \\
+13\end{array}$ & $\begin{array}{r}105 \\
+11\end{array}$ & $\begin{array}{r}105 \\
+19\end{array}$ & $\begin{array}{r}105 \\
+2\end{array}$ \\
\hline 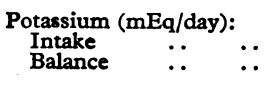 & $\begin{array}{r}88 \\
-6\end{array}$ & $\begin{array}{r}88 \\
+2\end{array}$ & $\begin{array}{r}88 \\
-10\end{array}$ & $\begin{array}{r}88 \\
-2\end{array}$ \\
\hline
\end{tabular}


the mean difference being $16 \%$ of the average control value, and the range being 5 to $23 \%$. Case 3 is of special interest because urine-calcium excretion before the administration of Fucidin was abnormally high, averaging $11.7 \mathrm{mEq} /$ day, with a range of 10 to $14.5 \mathrm{mEq} /$ day. With Fucidin there was a progressive fall of urine calcium to levels below $8 \mathrm{mEq} /$ day. Even after 30 days' administration of the drug the urine-calcium excretion was still low, averaging $6.6 \mathrm{mEq} /$ day. On stopping Fucidin there was a prompt rise of urine-calcium excretion to an average of $8.5 \mathrm{mEq} /$ day during the first five days. (Fig. 4, Table IV). Case 4 also had pronounced hypercalciuria with

TABLE IV.-Case 3. Metabolic Balance Data. (Food Intake : 2,070 Calories/Day)

\begin{tabular}{|c|c|c|c|c|}
\hline No. of Days: & 8 & $12 \mathrm{~A}^{*}$ & $3 \mathrm{~B}^{*}$ & 5 \\
\hline Treatment: & Nil & Fucidint & Fucidint & Nil \\
\hline 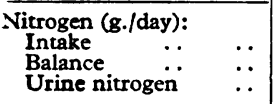 & $\begin{array}{r}21 \cdot 2 \\
+0 \cdot 7 \\
18 \cdot 8\end{array}$ & $\begin{array}{r}21.2 \\
-0.5 \\
19.7\end{array}$ & $\begin{array}{r}21 \cdot 2 \\
+1 \cdot 0 \\
18 \cdot 6\end{array}$ & $\begin{array}{r}21.2 \\
+1.7 \\
17.9\end{array}$ \\
\hline 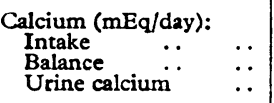 & $\begin{array}{c}141 \\
+22 \\
11.7\end{array}$ & $\begin{array}{c}141 \\
+20 \\
10.4\end{array}$ & $\frac{141}{6.6}$ & $\frac{141}{8.5}$ \\
\hline
\end{tabular}

- The administration of Fucidin was for 40 days. Study $A$ refers to the first 12 days, and Study $B$ to the last 3 days of the drug's administration. $t$ Dose of Fucidin: 2 g./day.

TABLE V.-Case 4. Metabolic Balance Data. (Food Intake : 2,390 Calories/Day)

\begin{tabular}{|c|c|c|}
\hline No. of Days: & 9 & 13 \\
\hline Treatment: & $\mathrm{Nil}$ & Fucidin* \\
\hline $\begin{array}{l}\text { Nitrogen (g./day): } \\
\begin{array}{l}\text { Intake } . . \\
\text { Balance } \\
\text { Urine nitrogen }\end{array}\end{array}$ & $\begin{array}{r}23 \cdot 9 \\
-0 \cdot 1 \\
22 \cdot 4\end{array}$ & $\begin{array}{r}23.9 \\
+1 \cdot 0 \\
21.3\end{array}$ \\
\hline 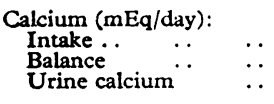 & $\begin{array}{l}165 \\
+18 \\
19 \cdot 7\end{array}$ & $\begin{array}{l}165 \\
+22 \\
16 \cdot 7\end{array}$ \\
\hline 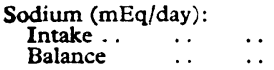 & $\begin{array}{r}107 \\
+\frac{10}{10}\end{array}$ & $\begin{array}{r}107 \\
+5\end{array}$ \\
\hline $\begin{array}{l}\text { Potassium (mEq/day): } \\
\begin{array}{c}\text { Intake } \\
\text { Balance }\end{array} \\
.\end{array}$ & $\begin{array}{r}88 \\
+9\end{array}$ & $\begin{array}{r}88 \\
+4\end{array}$ \\
\hline
\end{tabular}

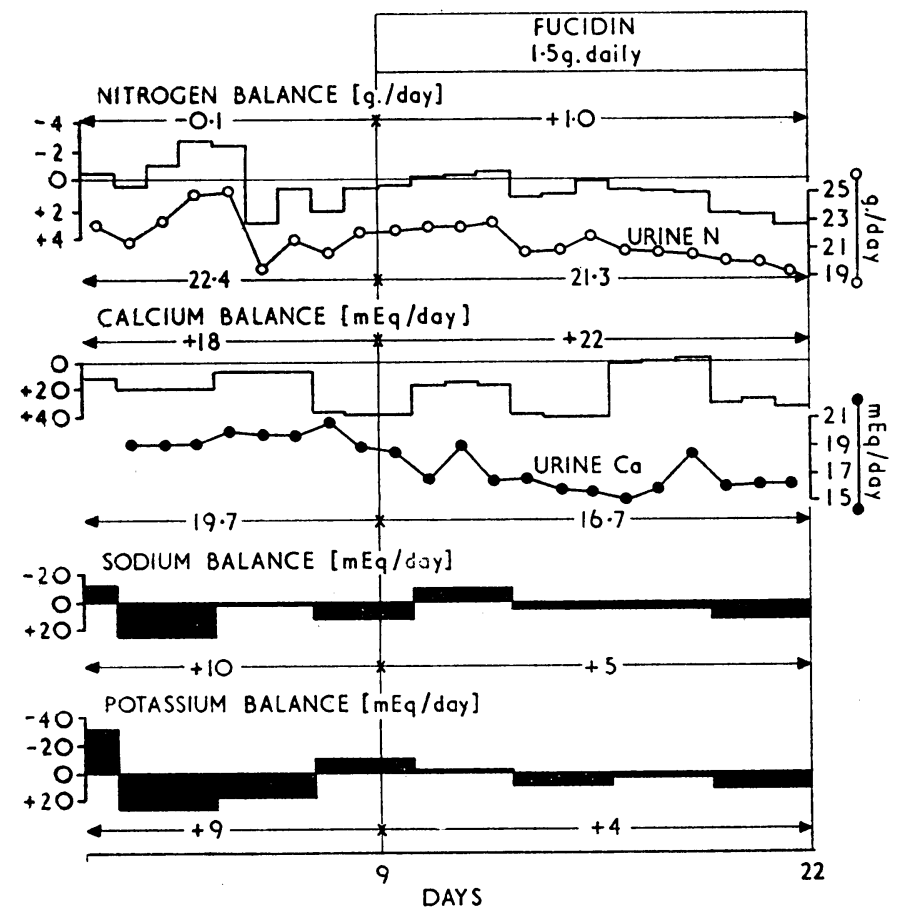

FIG. 5.-Metabolic data in Case 4. urine-calcium levels averaging $19.7 \mathrm{mEq}$ /day before treatment. These levels dropped to below $16 \mathrm{mEq} /$ day towards the end of the period of Fucidin administration (Fig. 5, Table V).

Sodium and Potassium Balance.-Data are available for five periods of observation in three patients (Cases 1, 2, and 4). There was no noticeable effect of Fucidin upon the external balance of sodium and potassium, or upon the urine and faecal excretion of these electrolytes.

\section{Liver-function Tests (Table VI)}

The only definite change observed in any liver-function test was decreased excretion of bromsulphthalein. This was observed in all ${ }^{1}$ of the patients, but the effect was slight in Case 4. Bromsulphthalein retention was most marked in the patient (Case 3) who received the largest dose of Fucidin. It was least marked in the one (Case 4) who received the smallest dose. The blood levels of Fucidin were $50 \mu \mathrm{g} . / \mathrm{ml}$. in Case 3 and 20 and $21 \mu \mathrm{g} . / \mathrm{ml}$. in Case 4 . These levels are consistent with the data contained in the manufacturer's reference manual. The differences in blood levels are due to the difference in dosage in the two patients.

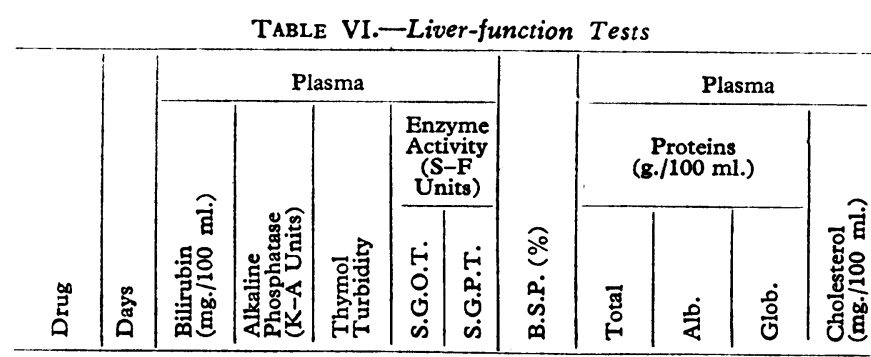

Case 1
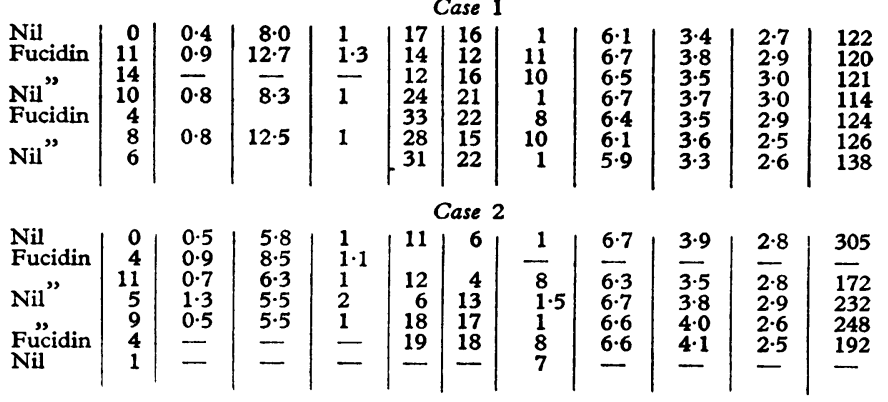

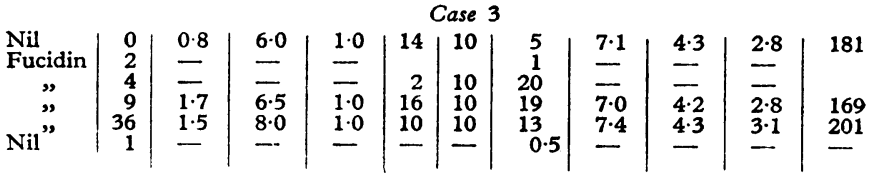

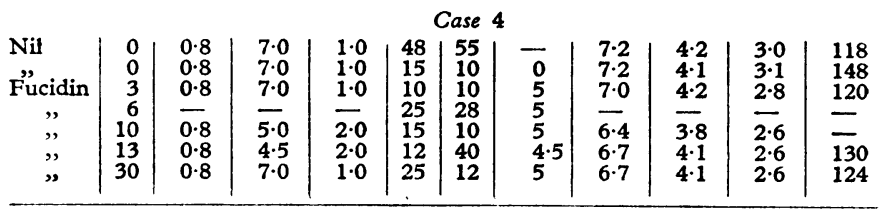

The effect upon bromsulphthalein excretion (Table VI) was not found after two days on the drug (Case 3), but was present after three days (Case 4) and four days (Case 3). One day after stopping the drug the bromsulphthalein retention fell from $13 \%$ to $0.5 \%$ in Case 3 .

Another possible abnormality was a slight elevation of the serum bilirubin from 0.8 to $1.7 \mathrm{mg} . / 100 \mathrm{ml}$. in Case 3 (Table VI). This change was not seen in the other cases. Moreover, in 6 additional patients receiving Fucidin for prolonged periods the plasma-bilirubin levels were normal.

${ }^{1}$ A further patient, not included in this study, also showed decreased bromsulphthalein excretion while receiving Fucidin. 


\section{Tests of Carbohydrate Metabolism}

Fucidin had no definite effect upon the fasting blood sugar or the oral glucose-tolerance test in three patients (Table VII). Sensitivity to insulin was unaffected by Fucidin in the one patient tested (Table VIII).

TABLE VII.-Oral Glucose-tolerance Tests in Cases 1, 2, and 4

\begin{tabular}{|c|c|c|c|c|c|c|c|c|}
\hline \multirow{2}{*}{ Drug } & \multirow{2}{*}{ Days } & \multicolumn{7}{|c|}{ Blood Sugar (mg./100 ml.) Minutes after Glucose } \\
\hline & & Fasting & 30 & 60 & 90 & 120 & 150 & 180 \\
\hline Case $1\left\{\begin{array}{l}\text { Nil } \\
\text { Fucidin }\end{array}\right.$ & 10 & $\begin{array}{l}70 \\
90\end{array}$ & $\begin{array}{l}102 \\
115\end{array}$ & $\begin{array}{l}120 \\
140\end{array}$ & $\begin{array}{l}110 \\
145\end{array}$ & $\begin{array}{l}105 \\
130\end{array}$ & $\begin{array}{l}97 \\
85\end{array}$ & $\begin{array}{l}60 \\
80\end{array}$ \\
\hline Case $2\left\{\begin{array}{l}\text { Nil } \\
\text { Fucidin }\end{array}\right.$ & 10 & $\begin{array}{l}85 \\
95\end{array}$ & $\begin{array}{l}115 \\
120\end{array}$ & $\begin{array}{l}115 \\
130\end{array}$ & $\begin{array}{l}115 \\
120\end{array}$ & $\begin{array}{r}90 \\
105\end{array}$ & $\begin{array}{l}88 \\
85\end{array}$ & $\begin{array}{r}85 \\
115\end{array}$ \\
\hline Case $4\left\{\begin{array}{l}\text { Nil } \\
\text { Fucidin }\end{array}\right.$ & 30 & $\begin{array}{l}80 \\
85\end{array}$ & $\begin{array}{l}135 \\
120\end{array}$ & $\begin{array}{l}120 \\
105\end{array}$ & $\begin{array}{r}75 \\
100\end{array}$ & $\begin{array}{r}100 \\
90\end{array}$ & $\begin{array}{r}100 \\
95\end{array}$ & $\overline{-}$ \\
\hline
\end{tabular}

TABLE VIII.-Case 4. Insulin-sensitivity Test, and Plasma-cortisol Response

\begin{tabular}{c|c|c|c|c|c|c|c|c|c|c}
\hline \multicolumn{6}{|c}{ Minutes after Insulin (0.15 unit/kg. of Body Weight) } \\
\hline $\begin{array}{c}\text { Fast- } \\
\text { ing }\end{array}$ & 10 & 20 & 30 & 40 & 50 & 60 & 75 & 90 & 105 & 120 \\
\hline
\end{tabular}

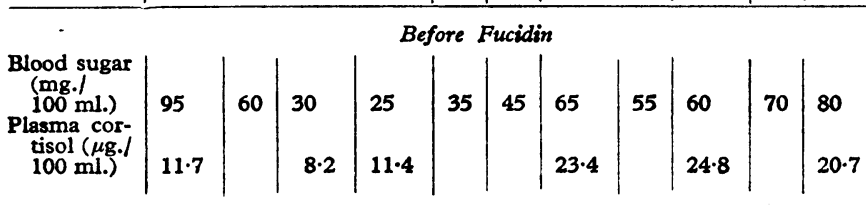
10 Days of Fucidin*

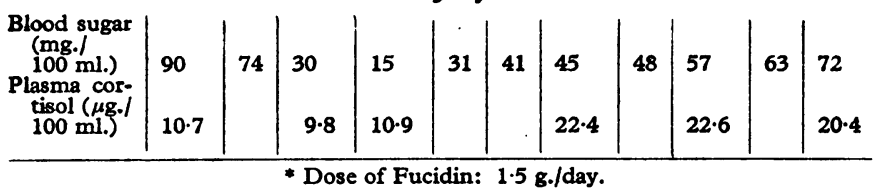

\section{Tests of Adrenal and Pituitary Function}

Fucidin had no effect upon the fasting plasma-cortisol level (Tables VIII and IX). It did not affect the half-life of infused

\begin{tabular}{|c|c|c|c|c|c|c|c|}
\hline \multirow{2}{*}{ Treatment } & \multirow[b]{2}{*}{ • } & \multicolumn{6}{|c|}{ Time in Minutes } \\
\hline & & Pre & 45 & 90 & 120 & 180 & 240 \\
\hline \multicolumn{8}{|c|}{ Case 1} \\
\hline Nil & $\begin{array}{l}\text { Blood cortisol } \\
\text { ( } \mu \mathrm{g} . / 100 \mathrm{ml} .) \\
\text { Cortisol half-life } \\
\text { (min.) } \\
\text { (.) }\end{array}$ & $\begin{array}{l}4 \cdot 3 \\
90\end{array}$ & - & $34 \cdot 4$ & $24 \cdot 7$ & $17 \cdot 8$ & $10 \cdot 1$ \\
\hline $\begin{array}{l}\text { Fucidin } \\
12 \text { days }\end{array}$ & $\begin{array}{l}\text { Blood cortisol } \\
\text { ( } \mu \mathrm{g} . / 100 \mathrm{ml} .) \\
\text { Cortisol half-life } \\
\text { (min.) }\end{array}$ & $\begin{array}{l}5 \cdot 2 \\
87\end{array}$ & $48 \cdot 9$ & $39 \cdot 5$ & $28 \cdot 2$ & $20 \cdot 2$ & $12 \cdot 2$ \\
\hline \multicolumn{8}{|c|}{ Case 2} \\
\hline Nil & $\begin{array}{l}\text { Blood cortisol } \\
(\mu \mathrm{g} . / 100 \mathrm{ml} .) \\
\text { Cortisol half-life } \\
(\min .)\end{array}$ & $\begin{array}{r}3 \cdot 2 \\
105\end{array}$ & $48 \cdot 7$ & $35 \cdot 4$ & $31 \cdot 4$ & $22 \cdot 0$ & $14 \cdot 0$ \\
\hline $\begin{array}{l}\text { Fucidin } \\
11 \text { days }\end{array}$ & $\begin{array}{l}\text { Blood cortisol } \\
\text { ( } \mu \mathrm{g} . / 100 \mathrm{ml} \text {.) } \\
\text { Cortisol half-life } \\
(\mathrm{min} .)\end{array}$ & $\begin{array}{r}8 \cdot 7 \\
114\end{array}$ & 47 & 38.9 & $31 \cdot 1$ & $23 \cdot 5$ & $15 \cdot 7$ \\
\hline
\end{tabular}

* $1 \mathrm{mg}$. cortisol per kg. in $200 \mathrm{ml} .5 \%$ fructose infused over 30 minutes.

TABLE X.-Urine 17-Oxosteroids, and 17-Oxogenic Steroid Excretion (mg./day)

\begin{tabular}{|c|c|c|c|c|}
\hline & Treatment & Days & 17-OXS & 17-OXGS \\
\hline Case 1 & . $\left\{\begin{array}{c}\text { Nil } \\
\text { Fucidin } \\
" \\
"\end{array}\right.$ & $\begin{array}{l}- \\
5 \\
6 \\
7 \\
8\end{array}$ & $\begin{array}{l}3 \cdot 1 \\
3.7 \\
3.5 \\
3.7 \\
4 \cdot 1 \\
4 \cdot 0\end{array}$ & $\begin{array}{l}7 \cdot 1 \\
6 \cdot 8 \\
6 \cdot 9 \\
7 \cdot 7 \\
9 \cdot 2 \\
6 \cdot 5\end{array}$ \\
\hline Case 2 & $\cdots\left\{\begin{array}{c}\text { Nil } \\
\text { Fucidin } \\
" \\
" \\
"\end{array}\right.$ & $\begin{array}{r}\overline{7} \\
1 \\
2 \\
6 \\
9 \\
10\end{array}$ & $\begin{array}{l}5 \cdot 2 \\
6 \cdot 3 \\
5 \cdot 7 \\
7 \cdot 1 \\
3 \cdot 4 \\
5 \cdot 1 \\
6 \cdot 9\end{array}$ & $\begin{array}{r}9 \cdot 0 \\
8 \cdot 6 \\
13 \cdot 0 \\
12 \cdot 2 \\
12 \cdot 2 \\
13 \cdot 7 \\
10 \cdot 3\end{array}$ \\
\hline
\end{tabular}

cortisol (Table IX). The urine excretion of 17-oxosteroids (17-OXS) and of oxogenic steroids (17-OXGS) was not affected by Fucidin (Table X). The response of the urine 17-OXGS to metyrapone was normal (Table XI). The plasma-cortisol response to induced hypoglycaemia was normal (Table VIII).

TABLE XI.-Case 3. Urine 17-Oxogenic Steroid Response to

\begin{tabular}{|c|c|c|c|c|c|c|}
\hline & & tme & & & Days & 17 OXGS (mg./day) \\
\hline $\begin{array}{l}\text { Nil } \\
\text { Fucidin* } \\
\text { Fucidin }\end{array}$ & $\begin{array}{l}\cdots \\
\therefore\end{array}$ & $\begin{array}{l}\because . \\
\because \\
\cdots\end{array}$ & $\begin{array}{l}\ddot{.} \\
\ddot{*}\end{array}$ & $\ddot{0}$ & $\overline{\overline{14}}$ & $\begin{array}{r}8.7 \\
5.6 \\
31.6 \\
33.7\end{array}$ \\
\hline
\end{tabular}

- The metyrapone was given in doses of $1.5 \mathrm{~g}$. eight-hourly on day 14 .

\section{Faecal Fat Excretion}

Cases 1 and 2 had faecal fat estimations carried out throughout the whole period of their metabolic study. In both cases the fat excretion was well within normal limits, being below 7 g./day (as stearic acid). Fucidin had no effect upon the faecal fat excretion.

\section{Plasma Electrolyte and Urea Levels}

Fucidin had no effect upon the plasma-electrolyte levels, including plasma calcium, or upon the level of plasma urea (Table XII).

\begin{tabular}{|c|c|c|c|c|c|c|}
\hline \multirow{2}{*}{ Drug } & \multirow{2}{*}{ Days } & $\mathrm{Na}^{+}$ & $\mathbf{K}^{+}$ & T.CO, & Urea & $\mathrm{Ca}^{++}$ \\
\hline & & \multicolumn{3}{|c|}{$\mathrm{mEq} / 1}$. & \multicolumn{2}{|c|}{$\mathrm{mg} / 100 \mathrm{ml}$} \\
\hline Case $2\left\{\begin{array}{l}\text { Nil } \\
\text { Fucidin }\end{array}\right.$ & $\overline{9}$ & $\begin{array}{l}140 \\
137\end{array}$ & $\begin{array}{l}3 \cdot 8 \\
4 \cdot 0\end{array}$ & $\begin{array}{l}27 \cdot 0 \\
27 \cdot 5\end{array}$ & $\begin{array}{l}29 \\
35\end{array}$ & $\begin{array}{l}9.5 \\
9.1\end{array}$ \\
\hline Case $3\left\{\begin{array}{l}\text { Nil } \\
\text { Fucidin }\end{array}\right.$ & $\overline{36}$ & $\begin{array}{l}136 \\
139\end{array}$ & $\begin{array}{l}4 \cdot 8 \\
4 \cdot 2\end{array}$ & $\begin{array}{l}27 \cdot 5 \\
26 \cdot 5\end{array}$ & $\begin{array}{l}38 \\
40\end{array}$ & $\begin{array}{l}9 \cdot 1 \\
8 \cdot 8\end{array}$ \\
\hline
\end{tabular}

\section{Discussion}

The positive metabolic findings in this investigation are a slight catabolic effect of Fucidin, a hypocalciuric effect, and a moderate reduction in bromsulphthalein excretion.

An increased urinary nitrogen excretion and decrease in external nitrogen balance indicate a catabolic or anti-anabolic effect of Fucidin. The effect was mild and of no apparent clinical significance. It has, however, some theoretical implications. Several antibiotics impair protein synthesis in the bacterial cell of sensitive species-for example, penicillin, the tetracyclines, and chloramphenicol-and the incorporation of amino-acids into cell wall peptides may also be reduced (Gale, 1960). It is possible that the host's tissue cells may be somewhat affected by the action of some antibiotics and that this will be reflected in decreased protein synthesis. This effect has been shown clearly in the case of the tetracycline group of antibiotics, although not for chloramphenicol (Bateman et al., 1952; Gabuzda et al., 1958 ; Shils, 1962, 1963). The mechanism of the catabolic or anti-anabolic action of antibiotics is not known, but it has been suggested that protein synthesis is blocked at the step in which soluble R.N.A. amino-acid complexes react with microsomal R.N.A. (Shils, 1962).

The catabolic effect of the tetracyclines assumes clinical importance when there is renal failure. In these circumstances the uraemia may worsen, especially if the dose of the antibiotic is not reduced to take into account the restricted ability of the kidneys to excrete the drug (Shils, 1962, 1963). While Fucidin shares with the tetracyclines a catabolic effect upon protein metabolism it is less likely than the tetracyclines to have noticeably enhanced effect in renal failure. Fucidin is not 
excreted to any extent by the kidneys (see below) and therefore will not accumulate in the blood in such patients. Moreover, judging by published data, the catabolic effect of Fucidin is somewhat less than that of the tetracyclines.

The hypocalciuric effect of Fucidin is difficult to explain. The simplest explanation would be that it causes a reduction in glomerular filtration rate. This explanation is unlikely because the blood-urea levels in the patients were not affected (Table XII). The plasma calcium was not significantly lowered by Fucidin (Table XII) so that hypocalcaemia is not likely to be the cause of the hypocalciuria.

There is no information upon the effect of other antibiotics upon urine-calcium excretion so that it is not possible to judge whether this effect is specific to Fucidin or not. Tetracyclines are strong chelating agents especially for divalent and trivalent cations (Weinberg, 1957). It is possible that fusidic acid may form stable chelates with $\mathrm{Ca}^{++}$, and, since little of the antibiotic is excreted in the urine, calcium may be diverted from the glomerular filtrate to be excreted together with fusidic acid in the gut. The observation of a hypocalciuric effect of Fucidin may ultimately be explicable upon some fundamental action of the drug as an antibiotic, but at the present time it is an observation without apparent clinical significance.

That Fucidin affects bromsulphthalein excretion by the liver is not unexpected. About $90 \%$ of injected bromsulphthalein is excreted by the liver (Lindquist and Paulsen, 1959), after being conjugated with cysteine and glutathione (Grodsky et al., 1959). To a very large extent Fucidin is excreted by the liver into the bile, mainly in an inactive form (Godtfredsen et al., 1962a, 1962b). The exact nature of the excretory products is not known, but presumably the fusidic acid is conjugated and then secreted by the liver cells into the bile canaliculi. Possibly the metabolites of fusidic acid share a common transport mechanism with the bromsulphthalein mercaptides and impede their excretion. The delayed excretion of bromsulphthalein due to Fucidin is unlikely to be a true toxic effect because it is reversible within one to three days after stopping the antibiotic. Moreover, there is no change in serum-enzyme activities to suggest a toxic effect of Fucidin upon the liver parenchyma.

The negative metabolic findings in this investigation are not without significance: the drug has no effect upon the conventional liver-function tests with the exception of bromsulphthalein excretion; it has no noticeable effect upon glucose tolerance or insulin sensitivity; and it does not affect the pituitary-adrenal axis or the metabolism of cortisol.

\section{Conclusion}

Although fusidic acid is a steroid whose fate in the body is not fully known, the studies reported here do not show any untoward metabolic effects which would reduce its value as an antibiotic in man.

\section{Summary}

Fucidin, the sodium salt of fusidic acid, is a steroid antibiotic related to helvolic acid and cephalosporin $P_{1}$. It was isolated from the fermentation products of the fungus, Fusidium coccineum. It has a high antibiotic activity against the staphylococcus and has proved itself to be a useful therapeutic substance in man. Its unique structure as an antibiotic prompted an investigation into its metabolic effects when given in therapeutic doses. It has been shown to have a mild protein catabolic effect, and to lower urinary calcium excretion. It causes mild temporary impairment of bromsulphthalein excretion by the liver. Fucidin had no noticeable effect upon external sodium and potassium balance, external calcium balance, liver function (except the bromsulphthalein test), carbohydrate metabolism, or the pituitary adrenal axis. Prolonged administration of Fucidin did not produce any significant derangement of metabolic balance in the cases studied.

I would like to express my thanks to the nursing and dietetic staff of the metabolic ward for their help in carrying out these studies. Many of the biochemical estimations were performed by the staff of the Department of Chemical Pathology, through the co-operation of Dr. B. J. Houghton and Dr. V. H. T. James. Dr. $M$. Feiwel kindly referred Cases 3 and 4 . Supplies of fusidic acid were donated by Leo Laboratories.

\section{REFERENCBS}

Allinger, N. L., and Coke, J. L. (1961). 7. org. Chem., 26, 4522.

Arigoni, D., von Daehne, W., Godtredsen, W. O., Melera, A., and Vangedal, S. (1964). Experientia (Basel), 20, 344 . Baird, B. M., Halsall, T. G., Jones, E. R. H., and Lowe, G. (1961).

Bateman, J. C., Barberio, J. R., Grice, P., Klopp, C. T., and Pierpont, H. (1952). Arch. intern. Med., 90, 763.

Crosbie, R. B. (1963). Brit. med. \%., 1, 788.

Dodson, B. (1963). Lancet, 2, 659.

Gabuzda, G. J., Gocke, T. M., Jackson, G. G., Grigsby, M. E., Love, B. D., and Finland, M. (1958). Arch. intern. Med., 101, 476.

Gale, E. F. (1960). Brit. med. Bull., 16,11.

Godtfredsen, W. O., Jahnsen, S., Lorck, H., Roholt, K., and Tybring, L. (1962a). Nature (Lond.), 193, 987.

- Roholt, K., and Tybring, L.'(1962b). Lancet, 1, 928.

Grodsky, G. M., Carbone, J. V., and Fanska, R. (1959). f. clin. Invest., 38, 1981 .

James, V. H. T., Landon, J., and Wynn, V. (1962). f. Fndocr., 25, 211.

Landon, J., Wynn, V., Cooke, J. N., and Kennedy, A. (1962a). Metabolism, 11, 501

- Houghton, B. J., and Cooke, J. N. (1962b). Ibid., 11, 513.

- and James, V. H. T. (1963). J. Endocr., 27, 183.

Lindquist, B., and Paulsen, L. (1959). Acta paediat. (Uppsala), 48, 233.

Schultz, J. C., Adamson, J. S., jun., Workman, W. W., and Norman, T. D. (1963). New Engl. F. Med., 269, 999.

Scowen, E. F., and Garrod, L. P. (1962). Lancet, 1, 933.

Shils, M. E. (1962). Clin. Pharmacol. Ther., 3, 321.

(1963). Ann. intern. Med., 58, 389.

Taylor, G., and Bloor, K. (1962). Lancet, 1, 935.

Weinberg, E. D. (1957). Bact. Rev., 21, 46.

Whalley, P. J., Adams, R. H., and Combes, B. (1964). F. Amer. med. Ass., 189, 357.

Wynn, V., Landon, J., and Kawerau, E. (1961). Lancet, 1, 69. 